\title{
eLXa: An Authoring Tool for the development Digital Education Resources ${ }^{+}$
}

\author{
Antonio Segura-Marrero *, Vanesa Martínez-Valderrey, Hugo Martínez-Martín and \\ Tania Rilova-García
}

College of Humanities and Social Sciences, Universidad Isabel I, 09003 Burgos, Spain; vanesa.martinez@ui1.es (V.M.-V.); hugo.martinez@ui1.es (H.M.-M.); tania.rilova@ui1.es (T.R.-G.)

* Correspondence: antonio.segura@ui1.es; Tel.: +34-947-671-731

+ Presented at the 2nd Innovative and Creative Education and Teaching International Conference (ICETIC2018), Badajoz, Spain, 20-22 June 2018.

Published: 8 November 2018

\begin{abstract}
Current development of educational resources for an online learning context has shown important shortcomings in answering the emerging teaching requests. The main objective of this study was to design a new authoring tool that could meet the needs of the eLearning sector that have become evident in the last decade. Additionally, the purpose was to guarantee the fulfillment of the accessibility principles in education. In order to guarantee accessibility to the system it is imperative that the teaching resources are able to adapt to the specific needs of individuals as well as to different technological demands.
\end{abstract}

Keywords: eLearning; accessibility; authoring tool; resources; digitals; Material Design; progressive enhancement

\section{Introduction}

Knowledge-based society [1-3] has promoted a constant change in a high number of professional areas. eLearning is not strange to this scenario and, in fact, is one of the engines of this change $[4,5]$. A fundamental element in this machinery are authoring tools, that is, software or apps to facilitate developing digital content in online education [6]. Literature review on the topic as well as practical application of a significant number of those tools showcases the ample selection existing and the difficulty associated to choosing when starting a new teaching plan.

eLXa intends to be an inclusive solution that integrates the strengths of its predecessors, is able to adapt to any technical development and, above all, can form and sustain a bond with people.

eLXa is not a mere adaption, but a new author tool born from current techno-pedagogical design ideas. It looks towards the future and can adapt to the emerging currents of design. That way, eLXa promotes a change in education following the pace set by knowledge-based society [7].

From this premise derive three main objectives: (1) Contributing innovation to the virtualization of teaching resources. (2) Improve accessibility, user-experience and learning-experience. (3) Include an emotional component together with gender equality considerations in digital learning resources.

\section{Design}

One of the keys in eXLa design was the interpretation and adaptation of Material Doc to a teaching context. This meant that the author tool resulting had a base in Material Design. This is particularly important when considering the enhancement of a friendly user-experience with a high learning curve given the daily contact with platforms such as Gmail, YouTube, Google Calendar, Google Drive, Twitter, etc. 
Material Design was born intending to become a universal design language by helping in the decision making process of areas related to design and programming. It provides a set of rules, guidelines, plugins and advice focused on improving the user-experience in places where variables such as creativity and customization play an essential role. Its willingness to become a standard [8] was another of the reasons considered in the design of eLXa, since it would allow for a transparent integration in multiple environments and in a clearly emerging tendency.

Throughout the design, much work has been done in user-interface (UI), physical aspects and site functionalities. Special attention was payed to the user-experience (UX), taking into account the interaction of people with the contents and the answers this will elicit in them [9]. Usability improving patterns [10] were included to this end, favoring sobriety and functionality over excessive ornamentation and extravagance. Steve Krug's five criteria of usability (2014) [11] were taken into account:

- Build of a clear visual hierarchy on each page.

- Use and exploitation of conventions.

- Page division in clearly defined zones.

- Clear signaling of clickable areas.

- Minimizing of visual noise.

Another of the keys in the development of this new tool was providing the teaching community with a software that aimed to generate digital teaching contents based on accessibility [12]. To this end, work followed with utmost respect the progressive enhancement principles [13]. This notion, that is also applicable to web design [14], comes from a clear premise: Content and functionalities of a website must be based on semantic HTML (which is recognized and understood by every browser) and every feature or enhancement (through style sheets or JavaScript) must be executed in a nonintrusive way. The ultimate aim is to be able to offer an assurance that all kinds of users will be able to access the content and will have a satisfying browsing experience [15] that will be improved as web languages and standards allow.

This premise implies a shift of focus and the dominant perspective in web creation: Graceful degradation. This paradigm, as opposed to the progressive enhancement, aims for the creation of web content that harnesses the advantages and possibilities offered by modern browsers to output the most attractive user-experience possible [16]. Once the final result is reached comes the implementation of accommodations for those users that for whatever reason cannot access the content as initially envisioned, even if it means a loss to the browsing experience.

Even if both concepts have the same objective, the perspective and approach is radically different. Progressive enhancement provides a content to be embellished, whereas graceful degradation brings accommodation. The drawback is that there are many situations in which one cannot foresee every possibility or scenario in which problems or incompatibilities will arise. Therefore, even if graceful degradation can bring the same result, it is more risky and difficult to achieve.

Another factor that influenced the design of eXLa was the gender perspective [17-19] as understood from a perspective of equality and inclusion and independent from the user's biological sex. The tool's interface presents a design that stays clear of androcentrist interpretations and favors a fair graphic representation of both gender [20] and the creation of digital learning resources with neutral (not sexist) language [21].

Last but not least, eXLa design took into account the existing relationship between userexperience and the emotion that binds it [22-24]. Far from wanting to satisfying a need or deficit, eXLa's emotional design focused on allowing the user to experiment psychological pleasure both through the virtualization of learning resources and when attaining the final results.

\section{Conclusions}

The practical application of this tool indicates that eLXa allowed the development of an authoring tool with the following functionalities and added values: 
- Search for a "universal access": Taking into account users with less advanced technology as well as users that rely on devices such as screen readers and other assistance tools.

- Use of eLXa facilitates and guides the user in the creation of contents that contribute to fulfilling the requirements and accessibility levels established by the main rules and standards.

- The creation process will always be accompanied by a graphic interface and a series of buttons and commands that allow every user the creation of content regardless of their knowledge of web creation languages. Thanks to a friendly, well designed, and usable interface, the learning process is intuitive and the learning curve is very high.

- The tool provides a high degree of freedom in content management, allowing the user to customize the screen learning experience according to their needs. Some of this customization include contrast settings, night mode, font size, keyboard navigation, computer to laptop vision, underlining, note-taking, activities ... As well as other types of interactions that improve not just the browsing experience but also the learning-experience (eLXa).

- The tool is based on the Google developed design called Material Design, generated from the best skeumorfism (real world mimicking design) and flat design (iconography, color and typography design). Since this a design language implemented in multiple Google products, especially Android's operative system, many users will be already familiar with in the interface.

- Allows cloud work, and therefore collaborative work from different places, in real and remote time, with the same contents.

- As for improving the learning-experience (eLXa), the tool allows for different export formats, from static to hypermedia, and it is able to adapt to the main compiling standards. This adaptability allows the integration in any kind of virtual environments for teaching and learning and any kind of formative typologies. It can also provide an answer to any learning theory and adapt to the many different principles of techno-pedagogical design.

- Promotes the creation of emotional answers and affective bonds adjusted to the use experience.

- Favors the design of digital learning resources from a gender perspective both in graphic and language form.

The synergy of all of these aspects aims to offer an innovative, engaged and friendly authoring tool that is easy to learn and present solutions for formative actions of many kinds, is able to adapt to different technologies and identify with people.

Supplementary Materials: The following are available online at http://www.elxa.es [25]

Author Contributions: A.S.-M. coordinated the actions and provided the techno-pedagogical vision as an eLearning specialist; V.M.-V. contributed the emotional and gender perspective in eLXa, H.M.-M. was the full stack developer; T.R.-G. worked in the web design, particularly in the interface and graphic content.

Conflicts of Interest: The authors declare no conflict of interest.

\section{References}

1. Bindé, J. Hacia las Sociedades del Conocimiento; UNESCO: París, France, 2005.

2. Mateo, J.L. Sociedad del Conocimiento. ARBOR 2006, 182, 145-151, doi:10.3989/arbor.2006.i718.18.

3. Mora, J.G. La necesidad del cambio educativo para la Sociedad del conocimiento. RIE 2004, 35, $13-37$. Available online: https://rieoei.org/historico/documentos/rie35a01.pdf (accessed on 5 April 2018).

4. Fernández, M.R.F.; Valverde, J.V.; Revuelta, F.I.R. Una revisión sobre la perspectiva social e-learning: TIC, inclusión digital y cambio social. RedES 2012, 49-63. Available online: http://ojs.udc.edu.co/index.php/ redes/article/download/1/6/0 (accessed on 5 April 2018).

5. Planella, J.; Rodríguez, I. Del e-learning y sus otras miradas: Una perspectiva social. RUSC 2004, 1, 7-20, doi:10.7238/rusc.v1i1.230.

6. Murray, T.; Blessing, S.; Ainsworth, S. Authoring Tools for Advanced Technology Learning Enviroments. Toward Cost-Effective Adaptive, Interactive and Intelligent Educacional Software; Kluwer Academic Publishers: Dordrecht, The Netherlands, 2003.

7. Castells, M. La Era de la Información; Alianza Editorial: Madrid, Spain, 1998. 
8. Zeldman, J.; Marcotte, E. Designing with Web Standards, 3rd ed.; New Riders (Pearson Education): Upper Saddle River, NJ, USA, 2009.

9. Hassan-Montero, Y. Factores del Diseño Web Orientado a la Satisfacción y No-Frustración de Uso. REDC 2006, 29, 239-257, doi:10.3989/redc.2006.v29.i2.291.

10. Nielsen, J.; Budiu, R. Usabilidad en Dispositivos Móviles; Ediciones Anaya Multimedia: Madrid, Spain, 2013.

11. Krug, S. Don't Make Me Think, a Common-Sense Approach to Web Usability, 3rd ed.; New Riders (Pearson Education): Upper Saddle River, NJ, USA, 2014.

12. Rodrigo-San Juan, C.; Delgado-Leal, J.L. y Sastre-Toral, T. Accesibilidad a los contenidos educativos audiovisuales: Nuevas tecnologías con formatos contenedores. [Container formats as a new technological mean for improving accesibility in audiovisual learning resources]. RIED 2010, 13, 107-131. Available online: http://revistas.uned.es/index.php/ried/article/viewFile/820/729 (accessed on 5 April 2018).

13. Gustafson, A. Adaptive Web Design, Crafting Rich Experiences with Progressive Enhacement; Easy Readers: Hermosa Beach, CA, USA, 2011.

14. Parker, T.; Toland, P.; Jehl, S. Designing with Progressi- Ve Engacement, Building the Web That Works for Everyone; New Riders (Pearson Education): Upper Saddle River, NJ, USA, 2010.

15. Tidwell, J. Designing Interfaces, Patterns for Effective Interaction Design; O'Reilly Media: Oakville, ON, Canada, 2011.

16. Garrett, J.J. The Elements of User Experience, 2nd ed.; New Riders (Pearson Education): Upper Saddle River, NJ, USA, 2011.

17. Connel, R. (1997). La organización social de la masculinidad. In Masculinidad/es: Poder y Crisis; Connel, R., Valdés, T., Olavarría, J., Eds.; ISIS-FLACSO: Santiago de Chile, Chile, 1997; Chapter 2, pp. 31-48.

18. Lamas, M. La Construcción Cultural de la Diferencia Sexual; PUEG: United Mexican States, Mexico, 1996.

19. Lamas, M. Género, Diferencia de Sexo y Diferencia Sexual. Cuicuilco: Nueva Época 2000, 7. Available online: http://www.redalyc.org/pdf/351/35101807.pdf (accessed on 5 April 2018).

20. Rovetto, F. Androcentrismo y medios de comunicación: Apuntes sobre la representación de las mujeres en la prensa de actualidad. Cuadernos de Información 2010, 43-52. Available online: http://www.ica2012.uc.cl/ prontus_fcom/site/artic/20101217/imag/FOTO_1620101217163732.pdf (accessed on 5 April 2018).

21. Rebollo, M.A.; García, R.; Vega, L.; Buzón, O. Barragán, R. Gender and ITC in Higher Education: Non-sexist virtual resources for learning. Cultura y Educación 2014, 21, 257-274, doi:10.1174/113564009789052316.

22. Desmet, P. A multilayered model of product emotions. Des. J. 2003, 6, 4-13, doi:10.2752/146069203789 355480

23. Jordan, P.W. Designing Pleasurable Products: An Introduction to the New Human Factors; CRC Press: Boca Raton, FL, USA, 2002.

24. Norman, D.A. Emotional Design: Why We Love (or Hate) Everyday Things; Basic Books: New York, NY, USA, 2004.

25. Elxa. http://www.elxa.es (archived on 19 June 2018).

(C) 2018 by the authors. Licensee MDPI, Basel, Switzerland. This article is an open access article distributed under the terms and conditions of the Creative Commons Attribution (CC BY) license (http://creativecommons.org/licenses/by/4.0/). 